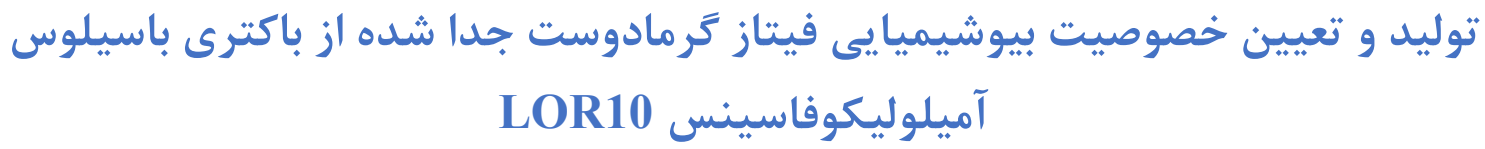

\begin{abstract}
ارسطو بدويى دلفارد و مريم يرهام فر
كروه زيست شناسى، دانشكده علوم، دانشكاه شهيد باهنر كرمان، كرمان، ايران

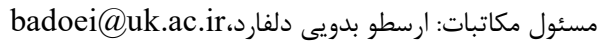

جكيده. فيتاز ارزش تغذيهاى غذاهاى گياهى را با افزايش هضميذيرى تروتئين و در دسترس سازى مواد معدنى از طريق هيدروليز فيتات در طى هضم در معده يا

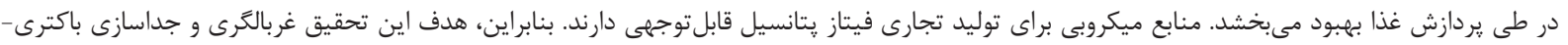

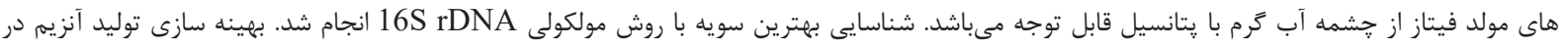

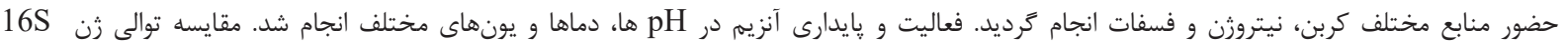

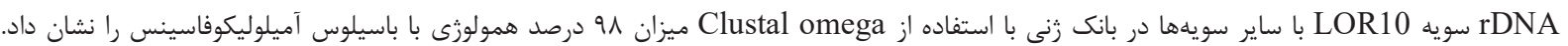

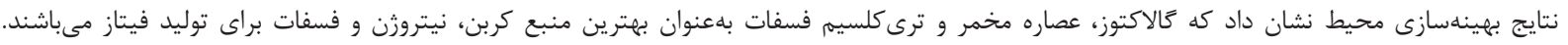

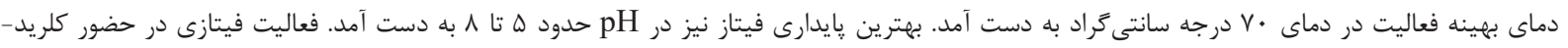

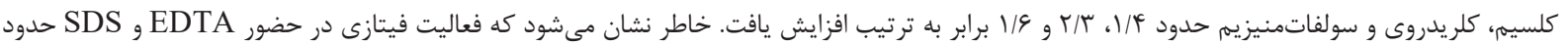

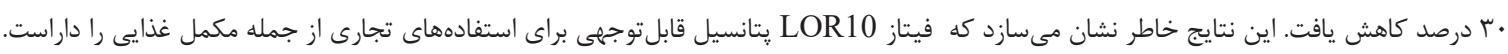
وازه هاى كليدى. باكترىهاى تجزيه كننده فيتات، جداسازى، جشمه آبكرم، شناسايى باكتريايى
\end{abstract}

\title{
Production and biochemical characterization of a thermostable phytase from Bacillus amyloliquefaciens LOR10
}

\author{
Arastoo Badoei-Dalfard \& Maryam Parhamfar \\ Department of Biology, Faculty of Sciences, Shahid Bahonar University of Kerman, Kerman, Iran \\ Correspondent author: Arastoo Badoei-Dalfard, badoei@uk.ac.ir
}

\begin{abstract}
Phytase can improve the nutritional value of plant-based foods by enhancing protein digestibility and mineral availability through phytate digestion in the stomach and the food processing industry. Microbial sources are more promising for the production of phytases on a commercial scale. The objectives of this exploration were to screening and isolation of phytase-producing bacteria from hot spring with commercial interest. Molecular identification of the best isolate was achieved by the $16 \mathrm{~S} r D N A$ gene. Optimization of phytase production was prepared in the presence of different phosphate, nitrogen, and carbon sources. Enzyme activity and stability were also explored in the presence of different $\mathrm{pHs}$, temperatures, and ion compounds. Comparing the $16 \mathrm{~S} r D N A$ gene sequence of the isolate LOR10 with those in GenBank using Clustal omega shows 98\% sequence homology with Bacillus amyloliquefaciens. Medium optimization studies showed that galactose, yeast extract, and tricalcium phosphate were the best sources of carbon, nitrogen, and phosphate for phytase production, respectively. The optimum temperature activity was also observed to be $70^{\circ} \mathrm{C}$. Phytase stability was at its optimum in a $\mathrm{pH}$ range of 5.0-8.0. Phytase activity increased in the presence of $\mathrm{CaCl}_{2}$, $\mathrm{ZnCl}_{2}$, and $\mathrm{MnSO}_{4}$ about 1.4, 2.3 and 1.6 folds, respectively. It could be mentioned that phytase activity decreased by about $30 \%$ in the presence of EDTA and SDS. On the basis of the results, it could be concluded that LOR10 phytase has a great potential for commercial interest as an additive to animal plant-based foods.
\end{abstract}

Keywords. bacterial identification, hot spring, isolation, phytate-degrading bacteria 


\section{INTRODUCTION}

Phytase catalyzes the hydrolysis of phytate (myoinositol-1,2,3,4,5,6-hexakis dihydrogen phosphate) through phytate digestion in the stomach and the food processing industry (In et al., 2004; Sapna \& Singh, 2016). Most of the plant seeds and their coproducts contain $1-2 \%$ phytic acid representing $>60 \%$ of their total phosphorus (Lei \& Porres, 2003; Puppala, et al., 2019). In monogastric or agastric animals, phytic acid is a polyanionic chelating agent that forms complexes with several divalent cations of primary nutritional importance, e.g., $\mathrm{Ca}^{2+}, \mathrm{Mg}^{2+}$, $\mathrm{Zn}^{2+}, \mathrm{Cu}^{2+}, \mathrm{Fe}^{2+}$, and $\mathrm{Mn}^{2+}$ (Gessler et al., 2018). Phytic acid can also form complexes with proteins and amino acids at both acidic and alkaline pHs (Saani et al., 2019). The resulting compounds are insoluble, difficult for humans to hydrolyze during digestion, and, thus are typically nutritionally less available for absorption (Afinah et al., 2010). Furthermore, the unutilized phytate from plant feeds becomes an environmental pollutant in the areas of intensive animal agriculture (Vasudevan et al., 2017). These problems can be overcome by supplementing the animal feed with phytases, which improve the nutritional status of the feed and further, declines environmental phosphorus pollution caused by the use of phosphorus in animal feed (Selle \& Ravindran, 2008; Singha \& Satyanarayana, 2011; Demir et al., 2018; Vasudevan et al., 2019).

Phosphate can be efficiently released from the phytate by phytase activity (Kumar et al., 2010). Phytase blended into the diets of poultry, swine, and fish to increase the availability of phosphorus, minerals, amino acids, and energy. The enzyme sequesters orthophosphate groups from the inositol ring of phytate to produce free inorganic phosphate (Baruah et al., 2007; Cao et al., 2007). Phytases are present in bacteria, fungi, animals, and plants. Commonly, the activity of an animal's phytase is insignificant compared to the phytase of microorganisms and plants (Lei et al., 2013). Phytases have been found in various microorganisms such as Aspergillus fumigatus (Vasudevan et al., 2017), Escherichia coli (Demir et al., 2018), Enterobacter sp.4 (Vasudevan et al., 2019), B. amyloliquefaciens (Selle \& Ravindran, 2008), Lactobacillus sanfranciscensis (Raghavendra \& Halami, 2009), Bacillus sp. (Choi et al., 2001), Raoultella sp. (Sajidan et al., 2004), Citrobacter braakii (Kim et al., 1998), and Mitsuokella jalaludinii (Lan et al., 2002). Owing to some properties such as catalytic productivity, substrate specificity, and resistance to proteolytic enzymes, bacterial phytases are a real alternative to the fungal enzymes (Konietzny \& Greiner, 2004).
Because of their great industrial significance, there is an ongoing interest in isolating new microbial producing phytase and optimization of enzyme production. Hence the aim of this study is the isolation of the bacteria with phytase producing ability and characterization of this enzyme.

\section{MATERIALS AND METHODS}

\section{Isolation of the phytate-degrading bacteria}

Samples were gathered from the Loriya hot spring in Jiroft, which located in the southeast of Iran. Approximately $5 \mathrm{ml}$ of these samples was injected in $50 \mathrm{ml}$ of the phytase-specific medium $[1.5 \%$ glucose, $0.5 \% \quad\left(\mathrm{NH}_{4}\right)_{2} \mathrm{SO}_{4}, \quad 0.05 \% \mathrm{KCl}, \quad 0.01 \%$ $\mathrm{MgSO}_{4} .7 \mathrm{H}_{2} \mathrm{O}, 0.01 \% \mathrm{NaCl}, 0.01 \% \mathrm{CaCl}_{2} .2 \mathrm{H}_{2} \mathrm{O}$, $0.001 \% \mathrm{FeSO}_{4}, 0.001 \% \mathrm{MnSO}_{4}$, pH 6.5 with $0.5 \%$ sodium phytate (Sigma)]. These flasks were maintained at $45{ }^{\circ} \mathrm{C}$, with $180 \mathrm{rpm}$ for three days. After that, $5 \mathrm{ml}$ of this culture was added to the same fresh medium and maintained in the same conditions. Finally, $0.1 \mathrm{ml}$ of this culture was streaked onto the phytase-specific medium and incubated at $65{ }^{\circ} \mathrm{C}$ for $48 \mathrm{~h}$. Bacterial colonies capable of hydrolyzing sodium phytate, which can be recognized by their surrounding clear halo, were obtained by re-plating single colonies (Chunshan et al., 2001). To find the optimum time of phytase production, Bacillus sp. LOR10 was cultured in phytase specific medium, samples were picked up at $24 \mathrm{~h}$ intervals, and the phytase activity was measured as described below.

\section{Measurement of phytase activity}

The phytase activity was investigated using a modified ferrous sulfate molybdenum blue system (Greiner et al., 1997). Briefly, $50 \mu l$ of the enzyme solution was incubated with $450 \mu$ of a substrate solution $(1.5 \mathrm{mM}$ sodium phytate in $0.25 \mathrm{M}$ sodium acetate buffer, $\mathrm{pH} 5.0$ ) at $45{ }^{\circ} \mathrm{C}$ for $30 \mathrm{~min}$. The reaction was then stopped by adding $0.5 \mathrm{ml}$ of $10 \%$ $(\mathrm{w} / \mathrm{v})$ trichloroacetic acid. After that, the released inorganic phosphate was analyzed by adding $1 \mathrm{ml}$ of color reagent, containing $1 \%(\mathrm{w} / \mathrm{v})$ ammonium molybdate, $3.2 \%(\mathrm{v} / \mathrm{v})$ sulfuric acid, and $7.2 \%(\mathrm{w} / \mathrm{v})$ ferrous sulfate, and the optical density measured at $700 \mathrm{~nm}$. All the phytase activity determinations were accomplished in three independent experiments. One unit (U) of phytase activity was defined as the amount of enzyme that released 1 micromole of phosphate per minute at $45{ }^{\circ} \mathrm{C}$. The investigational error was not ever over $7 \%$.

\section{PCR amplification and $16 S \mathrm{rDNA}$ sequencing}

Genomic DNA of Bacillus sp. LOR10 was extracted according to Sambrook and Russell protocols (Sambrook \& Russell, 2001), and its purity was checked by the A260/A280. Universal $16 S$ rDNA PCR forward primer 27F (5- 
AGTTTGATCCTGGCTCAG-3) and reverse primer 1492R (5-GGC/TACCTTGTTACGACTT-3) were used for the amplification of $16 S$ rDNA genes (Badoei-Dalfard \& Karami, 2013; Ramezani-pour et al., 2015). PCR program was achieved as follows: (1) $94{ }^{\circ} \mathrm{C}$ for $5 \mathrm{~min}$ as initial temperature, (2) a run of 30 cycles with each cycle consisting of $45 \mathrm{~s}$ at 94 ${ }^{\circ} \mathrm{C}, 45 \mathrm{~s}$ at $48{ }^{\circ} \mathrm{C}$ and $90 \mathrm{~s}$ at $72{ }^{\circ} \mathrm{C}$, and (3) $5 \mathrm{~min}$ at $72{ }^{\circ} \mathrm{C}$ to permit for the extension of any incomplete products (Azadian et al., 2016; Farahmand et al., 2019). PCR products were electrophoresed on agarose gel $(1.0 \%)$ and subsequently amplified $16 \mathrm{~S}$ rDNA bands were purified by DNA extraction kit (Sinaclon, Iran). Then DNA sequencing was performed on both strands directly by SEQ-LAB (Germany).

The phylogenetic tree was prepared based on the comparison of $16 \mathrm{~S} r D N A$ sequences of Bacillus sp. LOR10 strain with $16 S r D N A$ sequences of strains of Bacillus species stored in the GenBank database (http://www.ncbi.nlm.nih.gov). All sequences were aligned with Clustal Omega (version 6.0) that was obtained from http://www.seqtool.sdsc.edu/CGI/Om ega.cgi (Sievers et al., 2011), and the phylogenetic tree was prepared in MEGA5 (Tamura et al., 2007). The obtained $16 \mathrm{~S}$ rDNA sequence has been deposited in GenBank for isolate Bacillus sp. LOR10.

\section{Examination of culture condition for phytase production}

To determine the optimal condition for phytase production, Bacillus sp. LOR10 was inoculated into $50 \mathrm{ml}$ of the liquid medium in a $250 \mathrm{ml}$ Erlenmeyer flask and maintained on a shaker at $37^{\circ} \mathrm{C}$ for three days. Carbon, nitrogen, and phosphate sources were explored on the phytase production (Parhamfar et al., 2015; Parhamfar et al., 2016). Carbon sources were $1.5 \%$ glucose, $1.5 \%$ galactose, and $0.75 \%$ glucose $+0.75 \%$ galactose. Nitrogen sources were $0.5 \%$ glycine, $0.5 \%$ yeast extract, and $0.5 \%$ ammonium sulfate. Phosphate sources were sodium phytate $(0.5 \%)$, tricalcium phosphate $(0.5 \%)$, sodium phytate $(0.25 \%)+$ tricalcium phosphate $(0.25 \%)$, and nutrient broth. The effect of initial $\mathrm{pH}$ on phytase production was also explored by using phytase specific medium with $\mathrm{pH} 5.0,6.0$, and 7.0. Samples were picked up each $24 \mathrm{~h}$, and phytase activity was determined as described above.

\section{Partial purification of phytase}

Bacillus sp. LOR10 was grown up in nutrient broth medium for $16 \mathrm{~h}$ with $168 \mathrm{rpm}$. The liquid medium used for the production of phytase was composed of $\left[1.5 \%\right.$ glucose, $0.5 \%\left(\mathrm{NH}_{4}\right)_{2} \mathrm{SO}_{4}$, $0.05 \% \mathrm{KCl}, \quad 0.01 \% \quad \mathrm{MgSO}_{4} .7 \mathrm{H}_{2} \mathrm{O}, 0.01 \% \mathrm{NaCl}$, $0.01 \% \quad \mathrm{CaCl}_{2} .2 \mathrm{H}_{2} \mathrm{O}, \quad 0.001 \% \quad \mathrm{FeSO}_{4}, \quad 0.001 \%$ $\mathrm{MnSO}_{4}$, pH 6.5 with $0.5 \%$ sodium phytate]. The $\mathrm{pH}$ of the medium was adjusted to 6.8 before autoclave.
The medium was inoculated at $10 \%(\mathrm{v} / \mathrm{v})$ with a $16 \mathrm{~h}$ old culture and incubated at $37{ }^{\circ} \mathrm{C}$ with $190 \mathrm{rpm}$ shaking for $48 \mathrm{~h}$. After that, the culture medium was centrifuged at $10,000 \times \mathrm{g}$ for $10 \mathrm{~min}$ at $4{ }^{\circ} \mathrm{C}$. and subsequently, the supernatant was precipitated with $0-100 \%\left(\mathrm{NH}_{4}\right)_{2} \mathrm{SO}_{4}$ to fraction the proteins at $4{ }^{\circ} \mathrm{C}$. After centrifuging at $12,000 \times \mathrm{g}$ for $20 \mathrm{~min}$ at $4{ }^{\circ} \mathrm{C}$, the pellet was dissolved in a small amount of 10 $\mathrm{mM}$ sodium acetate buffer, $\mathrm{pH}$ 7.0, and dialyzed overnight against the same buffer. All the steps were carried out at $4{ }^{\circ} \mathrm{C}$. The concentrated sample was applied on a Q-sepharose column $(1.5 \times 24 \mathrm{~cm})$, which equilibrated with sodium acetate buffer (20 $\mathrm{mM}, \mathrm{pH}$ 7.0). The proteins were eluted at a flow rate of $1.0 \mathrm{ml} / \mathrm{min}$ with the same buffer with $\mathrm{NaCl}$ gradient $(0.0-1.0 \mathrm{M})$. All the steps were carried out at $4{ }^{\circ} \mathrm{C}$. Fractions with high phytase activity were pooled and concentrated. SDS-PAGE was also performed on slab gel containing $10 \% \quad(\mathrm{w} / \mathrm{v})$ polyacrylamide.

\section{Enzyme characterization}

The temperature activity profile of LOR 10 phytase was investigated from 30 to $90{ }^{\circ} \mathrm{C}$ with $10{ }^{\circ} \mathrm{C}$ intervals. The thermal stability profile was also considered by measuring the residual enzyme activity after incubating the LOR10 phytase in $0.25 \mathrm{M}$ sodium acetate $(\mathrm{pH} 6.5)$ at each temperature for $30 \mathrm{~min}$, and then the enzyme samples placed on ice. Finally, the residual activity was measured as the standard condition.

The $\mathrm{pH}$ activity profile was determined by measuring the LOR 10 phytase activity at $45^{\circ} \mathrm{C}$, and $\mathrm{pH}$ 3.0-11.0 using the following buffers; sodium acetate $(0.25 \mathrm{M}, \mathrm{pH} 3.0-6.0)$, Tris- $\mathrm{HCl}(0.25 \mathrm{M}, \mathrm{pH}$ 6.0-9.0), and glycine- $\mathrm{NaOH}(0.25 \mathrm{M}, \mathrm{pH} 9.0-11)$. For the $\mathrm{pH}$ stability assays, LOR10 phytase was incubated in the same buffers over a range of $\mathrm{pH}$ from 3.0 to 11.0 at $45{ }^{\circ} \mathrm{C}$ for $60 \mathrm{~min}$. The residual phytase activity was measured under the standard conditions ( $\mathrm{pH} 6.8,45^{\circ} \mathrm{C}, 30 \mathrm{~min}$ ).

LOR10 phytase activity in the presence of different ions was also investigated with the final concentration of $5 \mathrm{mM}$. For determining ion stability, the equal volumes of metal ions/SDS/ EDTA $(10 \mathrm{mM})$ were mixed with enzyme solution in $0.05 \mathrm{M}$ sodium acetate buffer. The mixture was incubated for $1.0 \mathrm{~h}$ at room temperature, and then the residual activity was measured as the standard condition.

\section{RESULTS}

\section{Isolation and identification of the phytase- producing bacteria}

A total of 85 bacterial species were isolated from Loriya hot spring in Jiroft, located in the southeast of Iran. This hot spring has $68^{\circ} \mathrm{C}$ temperature and 
$\mathrm{pH}$ 5.0. After phytase assay screening, the best isolate was selected based on a clear halo around the colony. This isolate was cultured in liquid media, and phytase production was considered. This strain was grown on the liquid medium containing sodium phytate as an inducer. The samples were picked up to measure the phytase activity at a $24 \mathrm{~h}$ interval. Results showed that the maximum enzyme production occurred after $40 \mathrm{~h}$ of incubation (Fig. 1A). It also results in Figure $1 \mathrm{~B}$ shows that $\mathrm{pH}$ decreased from 6.8 to 5.7 as enzyme production and phosphate solubilization increased.

PCR product of the $16 \mathrm{~S} r D N A$ gene was about $1500 \mathrm{bp}$, and its sequence was edited to a total length of $1260 \mathrm{bp}$. Comparing the $16 \mathrm{~S}$ rDNA gene sequence of the isolate LOR10 with those in GenBank using Clustal omega show 98\% sequence homology with $B$. amyloliquefaciens and the phylogenetic tree was created by the neighborjoining method by MEGA5 software (Fig. 2).
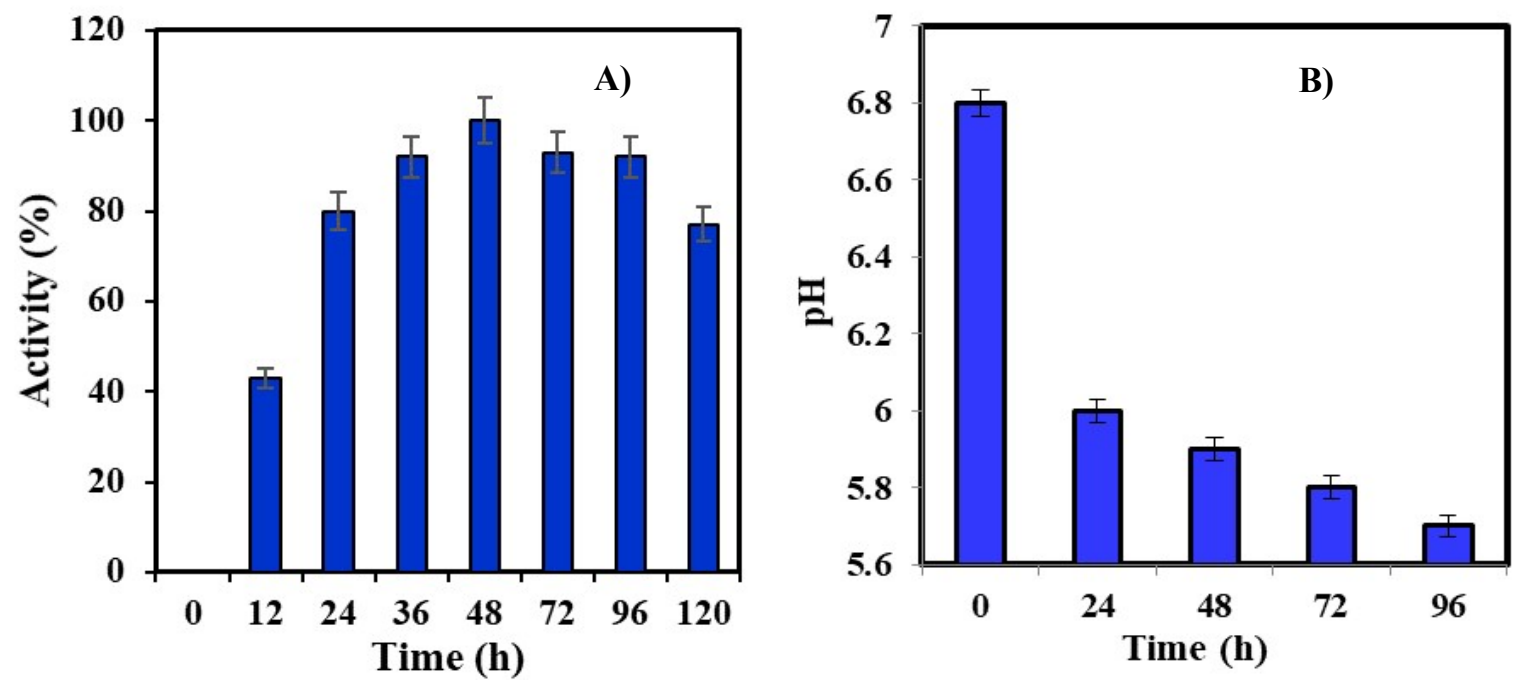

Figure 1. A. Time course of LOR10 phytase production. B. Time course of $\mathrm{pH}$ changes during incubation of Bacillus amyloliquefaciens LOR10.

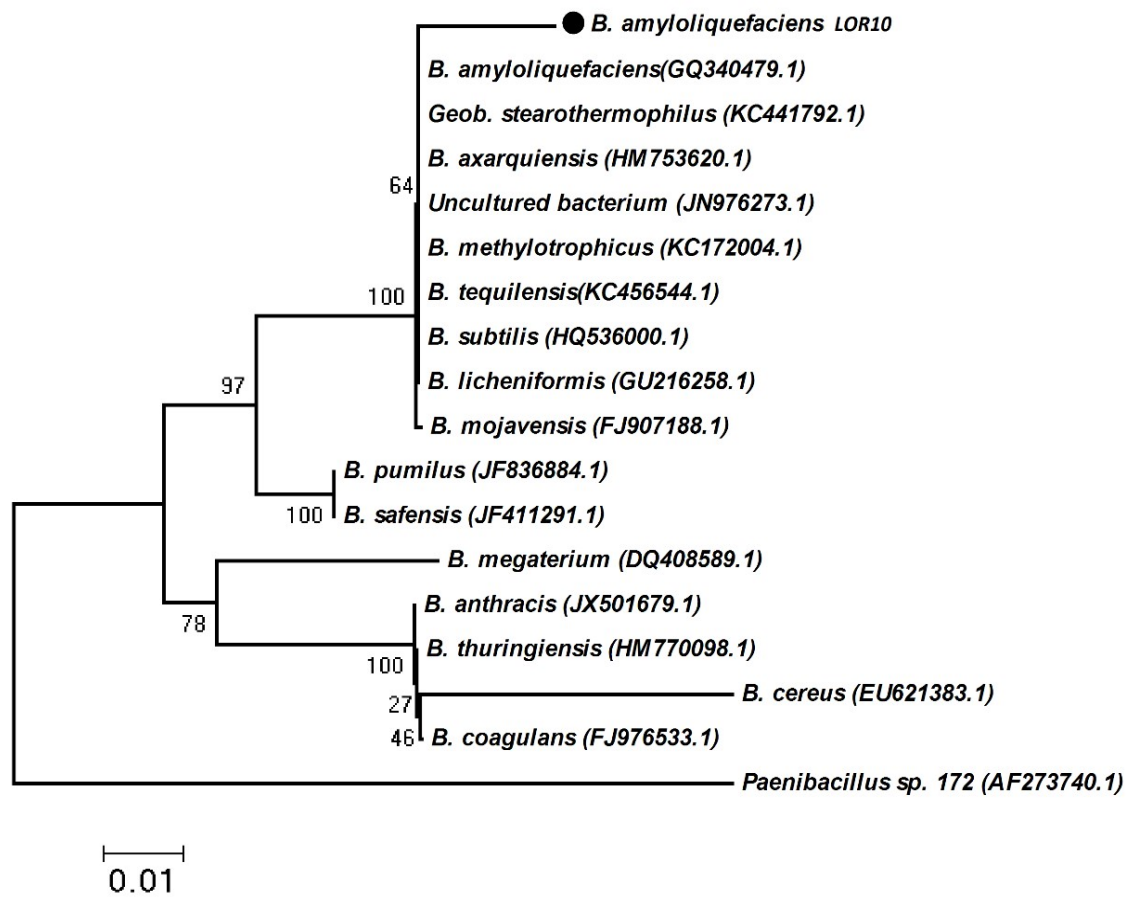

Figure 2. $16 S \mathrm{rDNA}$ based phylogenetic analysis of $B$. amyloliquefaciens LOR10. Bootstrap values and scale bar depicting substitution rate per site are indicated. The phylogenetic tree constructed by the neighbor-joining method showing the position of isolate LOR10. Paenibacillus sp. 172 was used as an outgroup. 


\section{Culture investigation for phytase production}

To conclude the best conditions for phytase production, the LOR10 isolate was cultured into 50 $\mathrm{ml}$ of the liquid medium in $500 \mathrm{ml}$ flask and maintained on a reciprocal at $37{ }^{\circ} \mathrm{C}$ for three days. Figures 3 and 4 displayed diverse sources of carbon, nitrogen, phosphate, and initial $\mathrm{pH}$ on phytase production. For carbon sources Glc (1.5\%), Gal $(1.5 \%)$, and Glc $(0.75 \%)+$ Gal $(0.75 \%)$ was added to the medium, and phytase activity was assayed at 24,48 , and $72 \mathrm{~h}$ of incubation. Results showed that all three carbon sources enhanced phytase production in 24 and $48 \mathrm{~h}$ of incubation and marginally decreased in $72 \mathrm{~h}$. High phytase activity was gotten in Gal (1.5\%) medium after $48 \mathrm{~h}$ of incubation (Fig. 3a). Results showed that glucose has less effect on phytase production.

The best nitrogen source for phytase production was yeast extract at $48 \mathrm{~h}$ of incubation. It was also 40 $\%$ and $50 \%$ more efficient than glycine and ammonium sulfate, respectively (Fig. $3 b$ ). Results showed that glycine had less effect on phytase production among these compounds.

The effect of initial $\mathrm{pH}$ on the phytase production by LOR10 isolate was also investigated. Results showed that $\mathrm{pH} 7.0$ was the optimum initial $\mathrm{pH}$ for phytase production after $24 \mathrm{~h}$ of incubation. But, after 48 and $72 \mathrm{~h}$ of incubation, $\mathrm{pH} 6.0$ showed the best results for phytase activity. It is mentioned that after $72 \mathrm{~h}$ incubation, $\mathrm{pH} 6$ showed 10 and 20\% more phytase activity than $\mathrm{pH} 5.0$ and 7.0, respectively (Fig. 4A).

The effect of phosphate salts, such as sodium phytate $(0.5 \%)$, tricalcium phosphate $(0.5 \%)$, sodium phytate $(0.25 \%)$ +tricalcium phosphate $(0.25 \%)$, and nutrient broth on phytase production is shown on Figure 4b. Results showed that tricalcium phosphate was the most suitable compound for phytase production. The nutrient broth has no significant effect on phytase production. A $30 \%$ enhancement in the phytase production achieved after the addition of tricalcium phosphate to the liquid medium.

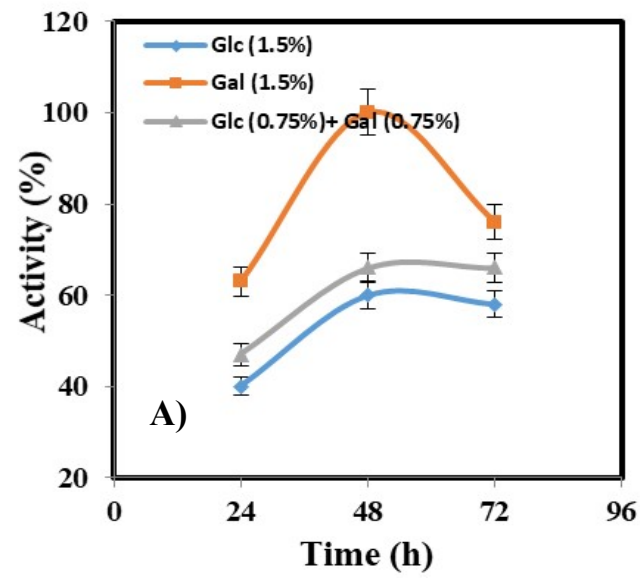

Figure 3. Effect of different carbon (A), nitrogen (B) on phytase production of B. amyloliquefaciens LOR10. Samples were picked up at $24 \mathrm{~h}$ intervals and phosphate solubilizing determined as described in material and methods.
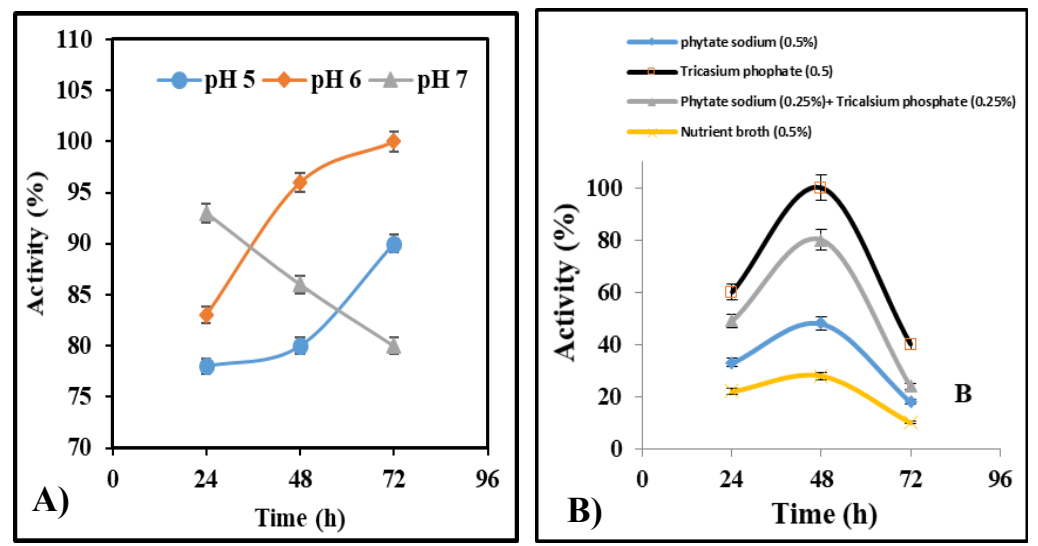

Figure 4. Effect of different initial $\mathrm{pH}(\mathbf{A})$ and phosphate sources (B) on phytase production of B. amyloliquefaciens LOR10. Samples were picked up at $24 \mathrm{~h}$ intervals and phosphate solubilizing determined as described in material and methods. 


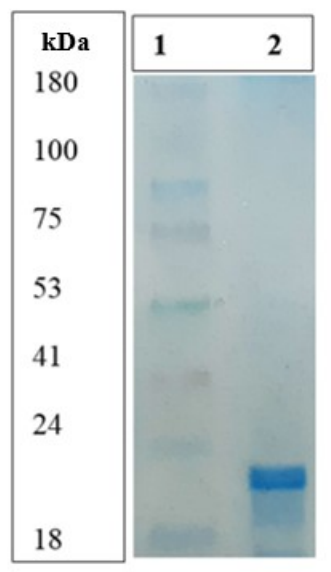

Figure 5. SDS-page of purified phytase from B. amyloliquefaciens LOR10 (2), protein markers (1).
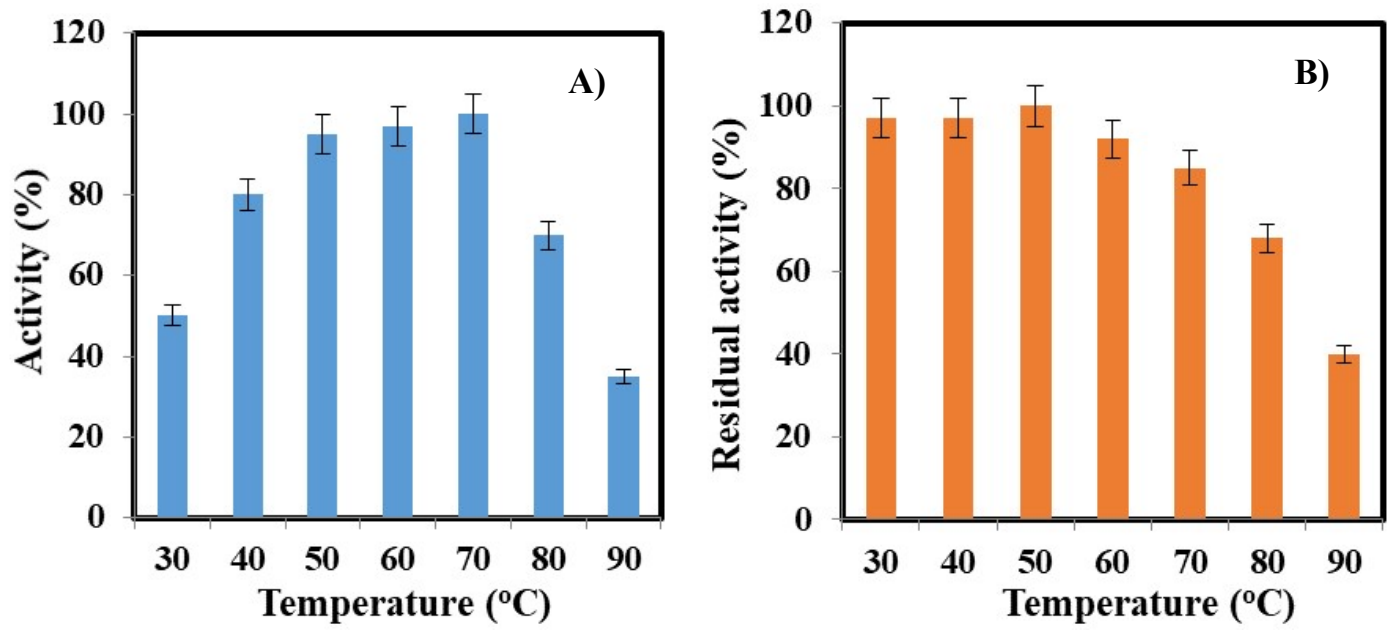

Figure 6. Temperature activity (A) and stability (B) profiles of LOR10 phytase. For temperature activity, the enzyme was assayed at different temperatures. For temperature stability, the enzyme was pre-incubated at different temperatures for $2 \mathrm{~h}$, and then the remaining activity was measured at the standard assay condition, which discussed in the materials and methods.
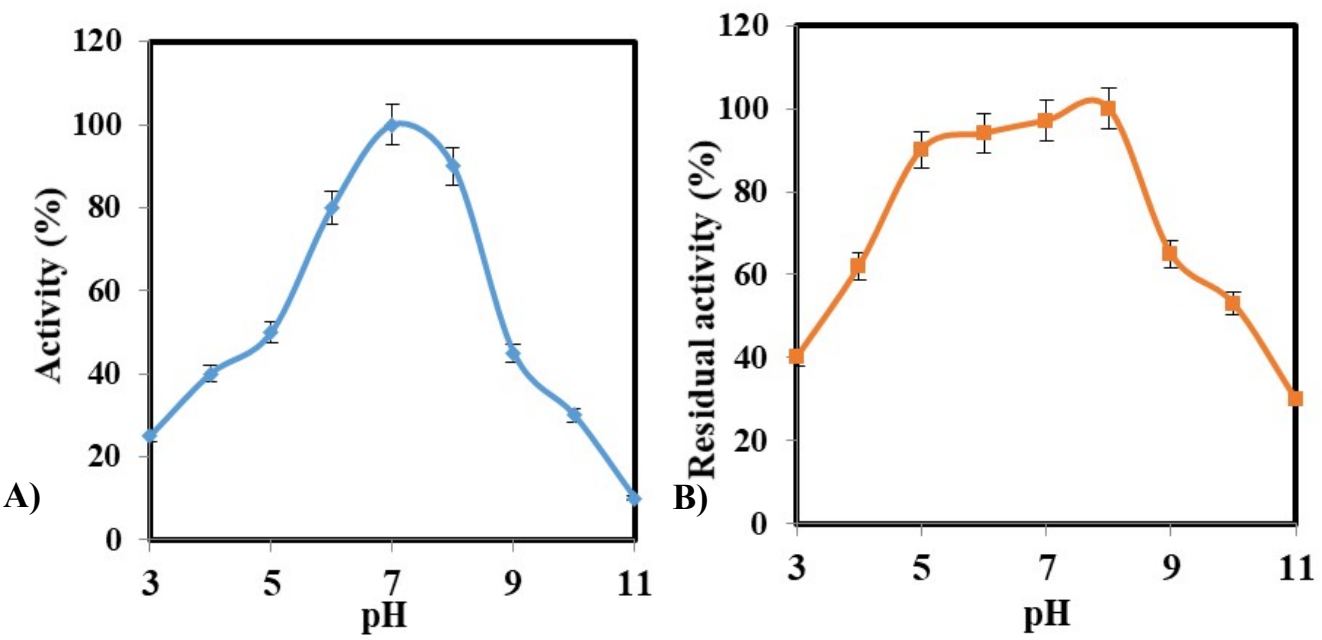

Figure 7. $\mathrm{pH}$ activity (A) and stability (B) profiles of LOR10 phytase. For pH activity, the enzyme was assayed at different $\mathrm{pHs}$. For $\mathrm{pH}$ stability, the enzyme was pre-incubated at different $\mathrm{pHs}$ for $2 \mathrm{~h}$, and then the remaining activity was measured at the standard assay condition, which discussed in the materials and methods. 
Table 1. Relative activity and stability of LOR 10 phytase in the presence of different ions and compounds

\begin{tabular}{lcc}
\hline & Relative activity (\%) & Relative stability (\%) \\
\hline $\mathrm{No}$ ion & $100 \pm 0$ & $100 \pm 0$ \\
$\mathrm{CaCl} 2$ & $142 \pm 1.2$ & $137 \pm 1.3$ \\
$\mathrm{MgCl} 2$ & $105 \pm 1.03$ & $112 \pm 1.3$ \\
$\mathrm{ZnCl} 2$ & $232 \pm 1.3$ & $125 \pm 1.1$ \\
$\mathrm{KCl}$ & $100 \pm 1.0$ & $100 \pm 1.1$ \\
$\mathrm{NaCl}$ & $100 \pm 0.9$ & $152 \pm 1.16$ \\
$\mathrm{MnSO} 4$ & $163 \pm 1.4$ & $192 \pm 1.5$ \\
$\mathrm{FeSO} 4$ & $70 \pm 0.2$ & $75 \pm 0.3$ \\
$\mathrm{EDTA}$ & $65 \pm 0.3$ & $90 \pm 0.8$ \\
$\mathrm{SDS}$ & $70 \pm 0.4$ &
\end{tabular}

\section{Phytase characterization}

SDS-Page results showed that the purified phytase from B. amyloliquefaciens LOR10 has a single band of about $22 \mathrm{kDa}$ (Fig. 5). A variety of molecular weight for phytases from other Bacillus species had been described as $41 \mathrm{kDa}$ from Bacillus subtilis (Farhat et al., 2008), $47 \mathrm{kDa}$ from Bacillus licheniformes (Tye et al., 2002), and $28 \mathrm{kDa}$ from Bacillus tequilensis Dm018 (Badoei-dalfard et al., 2019).

\section{Phytase activity and stability at different temperatures}

The temperature activity profile of LOR10 phytase was shown in Figure 6A. The optimal temperature activity was also detected in $70{ }^{\circ} \mathrm{C}$. LOR10 phytase showed about $35 \%$ activity in $90^{\circ} \mathrm{C}$. Results showed that the phytase activity was constant from 30 to $50^{\circ} \mathrm{C}$, and then regularly decreased (Fig. 6B).

\section{Phytase activity and stability at different $\mathrm{pH}$}

The $\mathrm{pH}$ activity profile of LOR10 phytase was shown in Figure 7. Results indicated that the LOR10 phytase showed maximum activity at $\mathrm{pH} 7.0$ (Fig. 7A). Also, $\mathrm{pH}$ stability results were presented in Figure 7B. These results indicated that LOR10 phytase was stable from $\mathrm{pH}$ 5.0-8.0.

Effect of metal ion on phytase activity and stability

LOR10 phytase activity was also investigated at different ions. Results in Table 1 showed that the phytase activity had no change in the presence of $\mathrm{MgCl}_{2}, \mathrm{KCl}$, and $\mathrm{NaCl}$. Phytase activity in the presence of $\mathrm{CaCl}_{2}, \mathrm{ZnCl}_{2}$, and $\mathrm{MnSO}_{4}$ was increased about $1.4,2.3$, and 1.6 folds, respectively. It is mentioned that the phytase activity decreased by about $70 \%$ in the presence of EDTA and SDS. Results of ion stability in Table 1 revealed that the phytase activity was improved by about $1.37,1.52$, and 1.92 folds in the presence of $\mathrm{CaCl}_{2}, \mathrm{NaCl}$, and $\mathrm{MnSO}_{4}$, respectively.

\section{DISCUSSION}

A phytase-producing bacterium has been isolated from Loriya hot spring, that it is closely related to
Bacillus amyloliquefaciens. The ideal enzyme creation was revealed after $40 \mathrm{~h}$ of cultivation in the liquid medium. Carbon sources investigation results showed that the high phytase activity (100\%) was obtained in galactose medium after two days of incubation, compared to phytase activity $(60 \%)$ of the glucose medium.

The effect of different parameters on phytase production was also investigated based on previous reports (Parhamfar et al., 2016; Kim et al., 2002). However, phytase production by Bacillus subtillus using different carbon sources showed that glucose was the best carbon source (Kim et al., 2002). Nitrogen sources investigation showed that yeast extract had the best effect on the phytase production after $48 \mathrm{~h}$ of incubation. Ammonium sulfate and glycine have less effect about 60 and $40 \%$ on phytase production in the same condition. It was also earlier described that the addition of yeast extract $(0.01 \%)$ to culture improved phosphate solubilizing capacity of Pseudomonas sp.2 about $44 \%$. The same results were also reported by Kim and coworkers. They indicated that yeast extract was the better nitrogen source for the phytase production by strain BPTK4 (Kim et al., 2002). The value of phytase production in the presence of different $\mathrm{pHs}$ showed that $\mathrm{pH} 6.0$ was more effective than $\mathrm{pH} 5.0,7.0$ after $72 \mathrm{~h}$ of incubation. Interestingly, phytase production was gradually decreased in $\mathrm{pH} 7.0$ but gradually increased in $\mathrm{pH}$ 5.0. It was also stated that the optimal $\mathrm{pH}$ by Pseudomonas sp. YH40 for phytase production was pH 6.0 (Kim et al., 2002). Phosphate sources exploration showed that tricalcium phosphate was the best phosphate source for phytase production. It was previously reported that none of the phosphate salts (calcium phytate, sodium phytate, $\mathrm{K}_{2} \mathrm{HPO}_{4}$, and $\mathrm{Na}_{2} \mathrm{HPO}_{4}$ ) had any effect on increasing phytase production by Pseudomonas sp. YH40 (Kim et al., 2002). The addition of $\mathrm{KCl}$ and $\mathrm{FeSO}_{4}$ to the medium showed the same results as Bacillus sp.C43 phytase (Sreedevi \& Reddy, 2012). LOR10 phytase 
has more than $90 \%$ of its stability in 40 to $60{ }^{\circ} \mathrm{C}$. This phytase displayed about $60 \%$ of its initial activity in $80^{\circ} \mathrm{C}$. The thermal stability of phytase is deliberated to be an important and valuable principle for application as an animal additive. Power and Jagannathan described a phytase that displayed optimal activity at a temperature of $60{ }^{\circ} \mathrm{C}$ and was stable up to $70{ }^{\circ} \mathrm{C}$ (Powar \& Jagannathan, 1982). Bacillus sp. (natto) phytase had an optimum temperature of $60^{\circ} \mathrm{C}$ (Shimizu, 1992). Although the maximum activity of LOR10 phytase was observed in $\mathrm{pH} 7.0$, it showed more than $40 \%$ of its activity in acidic $\mathrm{pH}$ (4.0-7.0). LOR10 phytase showed about $90 \%$ of its initial activity in the broad ranges of $\mathrm{pH}$ (5.0-8.0). The optimum $\mathrm{pH}$ activity of B. subtillus (natto) phytase was between 6.0-6.5 (Shimizu, 1992). $\mathrm{pH}$ stability of Pseudomonas sp. phytase was between $\mathrm{pH}$ 5.0-7.0, and the optimal $\mathrm{pH}$ of Pseudomonas sp. phytase was found $\mathrm{pH} 7.0$ (Kim et al., 2002).

For the investigation of the effects of the ions on phytase activity and stability, several different metal ions were examined (Table 1). Results showed that LOR10 phytase was inhibited by EDTA and SDS about $30 \%$, and stimulated by $\mathrm{CaCl}_{2}$ (1.4 fold), $\mathrm{ZnCl}_{2}$ (2.3 fold), and $\mathrm{MnSO}_{4}$ (1.6 fold). LOR10 phytase stability showed that $\mathrm{CaCl}_{2}, \mathrm{ZnCl}_{2}, \mathrm{NaCl}$, and $\mathrm{MnSO}_{4}$ stimulated phytase stability from 1.25 to 1.95 folds. It was also reported that $\mathrm{Ca}^{2+}$ was required for the activity of $B$. subtilis phytase, and had no critical effect on Bacillus phytase (Sreedevi \& Reddy, 2012), and had a slightly inhibitory effect on phytases from E. coli (Greiner \& Konietzny, 1993) and K. terrigena (Greiner et al., 1997). It was previously reported that positive monovalent cations did not influence on the alkaline phosphatase activity, while positive bivalent cations had different effects on the enzyme; $\mathrm{Mg}^{2+}, \mathrm{Ca}^{2+}, \mathrm{Co}^{2+}$, and $\mathrm{Mn}^{2+}$ activated the enzyme while $\mathrm{Zn}^{2+}, \mathrm{Cu}^{2+}$, and $\mathrm{Cd}^{2+}$ inhibited this enzyme (Kim et al., 2002).

Previous reports showed that SDS showed a strong inhibitory effect on other phytases, such as $A$. niger van Teighem phytase, Eupenicillium parvum BCC17694 phytase, and S. thermophile phytase (Vats et al., 2005; Singh et al., 2009; Fugthong et al., 2010). For example, A. niger van Teighem phytase lost $92 \%$ of its activity at $0.1 \%$ SDS.

Previous reports showed that metal ions could affect enzyme activity. Since metal ions act as Lewis acids, and coordination complexes of these can have different geometries, they may perform differently toward proteins as a ligand (Dokuzparmak et al., 2017). These differences may also result in metal binding to different sites, and, therefore, change the enzyme structure in different ways and affect the enzyme activity. Neira-Vielma and co-workers reported that the activity of the $A$. niger phytase increased in the presence of $\mathrm{Zn}^{+2}$ (Neira-Vielma et al., 2018), while phytase activity of B. subtilis CF92 (Hong et al., 2011) and L. plantarum, (Sumengen et al., 2012) was also inhibited in the presence of $\mathrm{Zn}^{+2}$.

Phytases of K. pneumoniae 9-3B and Bacillus subtilis were stimulated by EDTA (Kerovuo et al., 2000; Choi et al., 2001). It might be owing to the chelating of metal ions from the phytase complex, which decreases the $\mathrm{Km}$. Inhibition of alkaline phytase activity by EDTA has also been reported for the enzymes produced by Bacillus sp. DS11, Bacillus subtilis (Kim et al., 1998; Vohra and Satyanarayan, 2003), and Lactobacillus brevis phytase (Casey et al., 2003). The inhibition by EDTA indicates that some divalent ions are important for complete phytase activity. As mentioned above, EDTA removes divalent metal ions from proteins, thereby modifying their conformations (Ornela et al., 2019).

Finally, LOR10 phytase has engaging activity and stability under acidic $\mathrm{pH}$, excellent thermal stability, and fine ion activity and stability. So, LOR10 phytase can be applied as feed additives, as it could release inorganic phosphate from feed during the digestion process of animals. Currently, phytase has emerged as the world's most extensively used food enzyme. It had been shown that the phytase enzyme has giant latent in food industrial zone for bread processing, isolation of plant proteins, grains wet milling, and cereal bran fractionation.

\section{ACKNOWLEDGEMENT}

The authors express their gratitude to the Research Council of the Shahid Bahonar University of Kerman (Iran) for its financial support during this project.

\section{REFERENCES}

Afinah, S., Yazid, A.M., Anis Shobirin, M.H. \& Shuhaimi, M. 2010. Phytase: application in food industry. Food Research International Journal 17: 1321.

Azadian, F., Badoei-dalfard, A., Namaki-Shoushtari, A. \& Hassanshahian, M. 2016. Purification and biochemical properties of a thermostable, haloalkaline cellulase from Bacillus licheniformis AMF-07 and its application for hydrolysis of different cellulosic substrates to bioethanol production. Molecular Biology Research Communications 5: 143-155.

Badoei-Dalfard, A. \& Karami, Z. 2013. Screening and isolation of an organic solvent tolerant-protease from Bacillus sp. JER02: activity optimization by response surface methodology. Journal of Molecular Catalysis B: Enzymatic 89: 15-23.

Badoei-Dalfard, A., Parhamfar, M. \& Karami, Z. 2019. Characterization of a thermostable, 
acidic-phytase from Bacillus tequilensis Dm018; medium optimization by response surface methodology. Catalysis Letters 149: 2961-2972.

Baruah, A., Sahu, N.P., Pal, A.K., Debnath, D., Yengkokpam, S. \& Mukherjee, S.C. 2007. Interactions of dietary microbial phytase, citric acid and crude protein level on mineral utilization by Rohu, Labeo rohita (Hamilton), Juveniles. Journal of the World Aquaculture Society 38: 238-249.

Cao, L., Wang, W., Yang, C., Yang, Y., Diana, J. \& Yakupitiyage, A. 2007. Application of microbial phytase in fish feed. Enzyme and Microbial Technology 40: 497-507.

Casey, A. \& Walsh, G. 2004. Identification and characterization of a phytase of potential commercial interest. Journal of Biotechnology 110: 313-322.

Choi, Y.M., Suh, H.J. \& Kim, J.M. 2001. Purification and properties of extracellular phytase from Bacillus sp. KHU-10. Journal of Protein Chemistry 20: 287292.

Chunshan, Q., Linghua, Z., Yunji, W. \& Yoshiyuki, O. 2001. Production of phytase in slow phosphate medium by a novel yeast candida krusei. Journal of Bioscience and Bioengineering 92: 154-160.

Demir, Y., Dikba, N. \& Beydemir, Ş. 2018. Purification and biochemical characterization of phytase enzyme from Lactobacillus coryniformis (MH121153). Molecular Biotechnology 60: 783-790.

Dokuzparmak, E., Sirin, Y., Cakmak, U. \& SaglamErtunga, N. 2017. Purification and characterization of a novel thermostable phytase from the thermophilic Geobacillus sp. TF16. International Journal of Food Properties 20: 1104-1116.

Farahmand, S., Fatemi, F. \& Hajihosseini, R. 2019. Sequencing of the rus gene before and after the mutation with DES in the bacterial Acidithiobacillus sp. FJ2. Nova Biologica Reperta 6: 50-60. (In Persian).

Farhat, A., Chouayekh, H., Farhat, M.B., Bouchaala, K. \& Bejar, S. 2008. Gene cloning and characterization of a thermostable phytase from Bacillus subtilis US417 and assessment of its potential as a feed additive in comparison with a commercial enzyme. Molecular Biotechnology 40: 127-135.

Fugthong, A., Boonyapakron, K., Sornlek, W., Tanapongpipat, S., Eurwilaichitr, L. \& Pootanakit, K. 2010. Biochemical characterization and in vitro digestibility assay of Eupenicillium parvum (BCC17694) phytase expressed in Pichia Pastoris. Protein Expression and Purification 70: 60-67.

Gessler, N.N., Serdyuk, E.G., Isakovaa, E.P. \& Deryabinaa, Y.I. 2018. Phytases and the prospects for their application. Applied Biochemistry and Biotechnology 54: 352-360.

Greiner, R., Haller, E., Konietzny, U. \& Jany, K.D. 1997. Purification and characterization of a phytase from Klebsiella terrigena. Archives of Biochemistry and Biophysics 341: 201-206.

Greiner, R., Konietzny, U. \& Jany, K.D. 1993. Purification and characterization of two phytases from
Escherichia coli. Archives of Biochemistry and Biophysics 303: 107-113.

Hong, S.W., Chu, I.H. \& Chung, K.S. 2011.Purification and biochemical characterization of thermostable phytase from newly isolated Bacillus Subtilis CF92. Journal of the Korean Society for Applied Biological Chemistry 54: 89-94.

In, M., Jang, J.E.S., Kim, Y.J. \& Oh, N.S. 2004. Purification and properties of an extracellular acid phytase from Pseudomonas fragi Y9451. Journal of Microbiology and Biotechnology 14: 1004-1008.

Kerovuo, J., Lappalainen, I. \& Reinikainen, T. 2000. The metal dependence of Bacillus subtilis phytase. Biochemical and Biophysical Research Communications 268: 365-369.

Kim Y.O., Kim, H.K., Bae, K.S., Yu, J.H. \& Oh, T.K. 1998. Purification and properties of a thermostable phytase from Bacillus sp. DS11. Enzyme and Microbial Technology 22: 2-7.

Kim, Y.H., Gwon, M.N., Yang, S.Y., Park, T.K., Kim, C.G., Kim, C.W. \& Song, M.D. 2002. Isolation of phytase-producing Pseudomonas sp. and optimization of its phytase production. Journal of Microbiology and Biotechnology 12: 279-285.

Kim, Y.O., Kim, H.K., Bae, K.S., Yu, J.H. \& Oh, T.K. 1998. Purification and properties of a thermostable phytase from Bacillus sp. DS11. Enzyme and Microbial Technology 22: 2-7.

Konietzny, U. \& Greiner, R. 2004. Bacterial phytase: potential application, in vivo function and regulation of its synthesis. Brazilian Journal of Microbiology 35: 11-18.

Kumar, V., Sinha, A.K., Makkar, H.P.S. \& Becker, K. 2010. Dietary roles of phytate and phytase in human nutrition: a review. Food Chemistry 120: 94559.

Lan, G.Q., Abdullah, N., Jalaludin, S. \& Ho, Y.W. 2002. Culture conditions influencing phytase production of Mitsuokella jalaludinii, a new bacterial species from the rumen of cattle. Journal of Applied Microbiology 93: 668-674.

Lei, X.G. \& Porres, J.M. 2003. Phytase enzymology, applications, and biotechnology. Biotechnology Letters 25: 1787-1794.

Lei, X.G., Weaver, J.D., Mullaney, E.J., Ullah, A.H. \& Azain, M.J. 2013. Phytase, a new life for an old enzyme. Annual Review of Animal Biosciences 1: 283-309.

Neira-Vielmaa, A.A., Aguilar, C.N., Ilyina, A., Contreras-Esquivel, J.C., Carneiroda-Cunha, M.G., Michelena-Álvarez, G. \& MartínezHernández, J.L. 2018. Purification and biochemical characterization of an Aspergillus niger phytase produced by solid-state fermentation using triticale residues as substrate. Biotechnology Reports 17: 4954.

Ornela, P.H. O. \& Guimarães, L. H. S. 2019. Purification and characterization of an alkalistable phytase produced by Rhizopus microsporus var. microsporus in submerged fermentation. Process Biochemistry 81: 70-76. 
Parhamfar, M., Badoei-Dalfard, A., Khaleghi, M. \& Hassanshahian, M. 2015. Purification and characterization of an acidic, thermophilic phytase from a newly isolated Geobacillus stearothermophilus strain DM12. Progress in Biological Sciences 5: 6173.

Parhamfar, M., Badoei-Dalfard, A., Parhamfar, M. \& Fahimi-Rad, S. 2016. Purification and characterization of an extracellular phosphatase enzyme from Bacillus spp. Journal of Cell and Molecular Research 8: 90-97.

Powar, V.K. \& Jagannathan, V. 1982. Purification and properties of phytate specific phosphatase from Bacillus subtilis. Journal of Bacteriology 151: 11021108.

Puppala, K.R., Bhavsar, K., Sonalkar, V., Khire, J.M. \& Dharne, M.S. 2019. Characterization of novel acidic and thermostable phytase secreting Streptomyces sp. (NCIM 5533) for plant growth promoting characteristics. Biocatalysis and Agricultural Biotechnology 18: 101-120.

Raghavendra, P. \& Halami, P.M. 2009. Screening, selection and characterization of phytic acid degrading lactic acid bacteria from chicken intestine. International Journal of Food Microbiology 133: 129134.

Ramezani-Pour, N., Badoei-Dalfard, A., NamakiShoushtari, A. \& Karami, Z. 2015. Nitrilemetabolizing potential of Bacillus cereus strain FA12; nitrilase production, purification, and characterization. Biocatalysis and Biotransformation 33: 156-166.

Saani, D.M., Lawal, O.T. \& Enujiugha, V.N. 2019. Purification and characterization of phytase from Aspergillus fumigatus isolated from African giant snail (Achatina fulica). Biocatalysis and Agricultural Biotechnology 17: 225-232.

Sajidan, A., Farouk, A., Greiner, R., Jungblut, P., Müller, E.C. \& Borriss, R. 2004. Molecular and physiological characterization of a 3-phytase from the Rhizobacterium Klebsiella pneumoniae ASR1. Applied Microbiology and Biotechnology 65: 110118.

Sambrook, J. \& Russell, D. 2001. Molecular cloning: a laboratory manual, Cold Spring Harbor, New York.

Sapna, J.J. \& Singh, B. 2016. Characteristics and biotechnological applications of bacterial phytases. Process Biochemistry 51: 159-169.

Selle, P.H. \& Ravindran, R. 2008. Microbial phytase in poultry nutrition. Livestock Science 113: 99-122.

Shimizu, M. 1992. Purification and characterization of a phytase from Bacillus subtilis (natto) N-77. Bioscience Biotechnology and Biochemistry 56: 1266-1269.
Sievers, F., Wilm, A., Dineen, D.G., Gibson, T.J., Karplus, K., Li, W., Lopez, R., McWilliam, H., Remmert, M., Söding, J., Thompson, J.D. \& Higgins, D.G. 2011. Fast, scalable generation of high-quality protein multiple sequence alignments using Clustal Omega. Molecular Systems Biology 7: 539-547.

Singh, B. \& Satyanarayana, T. 2009. Characterization of a HAP-phytase from a thermophilic mould Sporotrichum Thermophile. Bioresource Technology 100: 2046-2051.

Singha, B. \& Satyanarayana, T. 2011. Phytases from thermophilic molds: their production, characteristics and multifarious applications. Process Biochemistry 46: 1391-1398.

Songa, H.Y. Sheikha, A. F. E. \& Hu, D.M. 2019. The positive impacts of microbial phytase on its nutritional applications. Trends in Food Science and Technology 86: 553-562.

Sreedevi, S. \& Reddy, B.N. 2012. Isolation, screening and optimization of phytase production from newly isolated Bacillus sp.C43. International Journal of Pharma and Bio Sciences 2: 218-231.

Sumengen, M., Dincer, S. \& Kaya, A. 2012. Phytase production from Lactobacillus brevis. Turkish Journal of Biology 36: 533-541.

Tamura, K., Dudley, J., Nei, M. \& Kumar, S. 2007. MEGA4: molecular evolutionary genetics analysis (MEGA) software version 4.0. Molecular Biology and Evolution 24: 1596-1599.

Tye, A.J., Siu, F.K., Leung, T.Y. \& Lim, B.L. 2002. Molecular cloning and the biochemical characterization of two novel phytases from $B$. subtilis 168 and $B$. licheniformis. Applied Microbiology and Biotechnology 59: 190-197.

Vasudevan, U.M., Jaiswal, A.K., Krishna, S. \& Pandey, A. 2019. Thermostable phytase in feed and fuel industries. Bioresource Technology 278: 400407.

Vasudevan, U.M., Krishna, S., Jalaja, V. \& Pandey, A. 2017. Microbial phytase: impact of advances in genetic engineering in revolutionizing its properties and applications. Bioresource Technology 245: 17901799.

Vats, P. \& Banerjee, U. 2005. Biochemical characterization of extracellular phytase (myo-inositol hexakisphosphate phosphohydrolase) from a hyperproducing strain of Aspergillus Niger van Tieghem. Journal of Industrial Microbiology and Biotechnology 32: 141-147.

Vohra, A. \& Satyanarayana, T. 2003. Phytases: microbial sources, production, purification, and potential biotechnological applications. Critical Reviews in Biotechnology 23: 29-60.

How to cite this article:

Badoei-Dalfard, A. \& Parhamfar, M. 2021. Production and biochemical characterization of a thermostable phytase from Bacillus amyloliquefaciens LOR10. Nova Biologica Reperta 7: 390-399. 